DOI: https://doi.org/10.33330/jurteksi.v7i2.1060

Available online at http:/jurnal.stmikroyal.ac.id/index.php/jurteksi

\title{
IMPLEMENTASI TEKNOLOGI RFID SEBAGAI SISTEM KEAMANAN SEPEDA MOTOR BERBASIS MIKROKONTROLER ATMEGA 328
}

\author{
Adi Mas Afandi \\ Teknik Komputer, STMIK Royal Kisaran \\ Email: adimasafandi@gmail.com
}

\begin{abstract}
Abstrack: Motorcycle is one of the transportation tools that are widely used by the people. The community uses motorbikes as a means of daily transportation, whether it's for work, shopping or taking children to school. On the other hand, of course, theft of motor vehicles, especially motorbikes is increasing. Almost every day motorcycle theft occurs. From these problems, a double security system on a motorcycle is needed. The security system using RFID technology can only be accessed using one e-ID card. RFID technology installed on a motorcycle to provide additional security to avoid theft.
\end{abstract}

Keywords: e-KTP; Motorcycle; RFID; Security System

Abstrak: Sepeda motor adalah suatu alat transportasi yang sering digunakan oleh masyarakat. Masyarakat menggunakan sepeda motor sebagai alat trasportasi sehari-hari, baik itu untuk bekerja, berbelanja maupun mengantar anak kesekolah. Pada sisi lain, tentunya pencurian kendaraan bermotor, khususnya sepeda motor semakin banyak. Hampir setiap harinya pencurian sepeda motor terjadi. Dari permasalahan tersebut, dibutuhkan sistem keamanan ganda pada sepeda motor. Sistem keamanan dengan menggunakan teknologi RFID hanya bisa diakses menggunakan satu buah e-ktp. Teknologi RFID yang dipasang pada sepeda motor guna memberikan kemanan tambahan agar terhindar dari pencurian.

Kata kunci : e-KTP; RFID; Sepeda motor; Sistem Keamanan

\section{PENDAHULUAN}

Sepeda motor merupakan salah satu sarana transportasi yang banyak digunakan masyarakat, hal ini dikarenakan harganya yang terjangkau dan penggunaannya yang efisien [1]. Menurut Badan Pusat Statistik (BPS) Indosnesia, tercatat jumlah kendaraan bermotor khususnya provinsi sumatera utara pada tahun 2015 sebanyak 5.022.752 unit dan meningkat pada tahun 2017 menjadi 6.162.974 unit[2]. Dengan meningkatnya jumlah kendaraan yang ada serta kebutuhan hidup yang mendesak menyebabkan tindakan kasus kriminal meningkat.

Salah satu tindakan kriminal berupa pencurian sepeda motor yang semakin meningkat. Menurut data pada Badan Pusat Stasistik (BPS) Indonesia, tindak kejahatan terhadap Pencurian kendaraan bermotor memiliki angka yang meningkat. Pada tahun 2017, angka 
pencurian sepeda motor tercatat sebesar 1040 unit sedangkan pada tahun 2018, angkanya meningkat menjadi 2982 unit[2].

Dalam melakukan aksinya,
pencuri sering sekali menggunakan kunci letter $\mathrm{T}$ maupun cairan sebagai media perusak kunci kontak pada sepeda motor[3]. Pencurian sepeda motor ini sering terjadi dikarenakan kurangnya ketelitian pemilik maupun pengguna sepeda motor saat memarkirkan kendaraannya, dimana pemilik kendaraan tersebut hanya mematikan mesin saja. Ada juga sebagian pemilik sepeda motor menggunakan gembok kecil yang dipasang pada cakram roda depan motor untuk memberikan pengamanan ganda. Namun hal tersebut sangatlah tidak efisien, yang mana pemilik sepeda motor sering sekali lalai dalam melakukannya[4].

Dari pemaparan permasalahan yang ada. Dibutuhkan sebuah sistem keamanan yang dapat menghentikan, setidaknya dapat mengurangi kejahatan pencurian sepeda motor. Tentunya sistem kemanan yang dibutuhkan haruslah lebih efektif dan efisien dalam penggunaanya. Salah satu teknologi yang dapat diterapkan sebagai sistem keamanan pada sepeda motor ialah teknologi. Teknologi RFID telah banyak dikembangkan dan diterapkan diberbagai bidang seperti pendeteksian barang pada supermarket, pendeteksian kendaraan pada jalan tol bahkan pada sampai pada penerapan pada sistem keamanan[5].

RFID yang merupakan salah satu teknologi yang memanfaatkan gelombang radio untuk identifikasi sebuah objek target, yang mana pada RFID terdapt dua bagian yakni RFID reader dan RFID tag[6]. RFID reader dan RFID tag memiiki fungsi yang berbeda. RFID reader berfungsi sebagai komponen pembaca sinyal informasi khusus yang dipancarkan oleh RFID tag, sedangkan RFID tag merupakan komponen yang penyimpanan data pada sebuah chip ic yang nantinya data tersebut akan dibaca oleh RFID melalui frekuensi khusus[7].

Tentunya dalam membangun sistem keamanan ini tidak terlepas dari media pengontrolan. Arduino Uno yang merupakan salah satu media pengontrolan yang bersifat open-source yang dapat dikembangkan oleh siapa saja. Arduino uno juga terdari atas 2 bagian utama berupa perangkat keras dan perangkat lunak yaitu perangkat keras berupa papan kontrol sedangkan perangkat lunak berupa aplikasi yang disebut Arduino IDE[8]. Dalam peroses pembuatan programnya, arduino menggunakan bahasa pemrograman $\mathrm{C}$ yang sangat familiar bagi sebagian besar para pembuat program[9]. Arduino uno yang termasuk pengontrolan berbasis mikrokontroler Atmega 328 yang memiliki 14 pin input/output digital dan 6 pin input analog[10].

\section{METODE}

Penelitian ini dilakukan pada sebuah sepeda motor Yamaha Vixion $150 \mathrm{cc}$ berjenis motor sport. Dalam melakukan penelitian dibutuhkan waktu selama tiga bulan, yang dimulai dari bulan januari sampai bulan maret tahun 2021. Objek penelitian yang dilakukan adalah sistem keamanan dengan menggunakan modul RFID sebagai sistem keamanan pada sepeda motor yang dikendalikan oleh sebuah media pengontrolan yaitu mikrokontroler Arduino Uno. Alat-alat tersebut dirangkai sesuai dengan rancangan gambar rangkaian maupun programnya, 
sehingga alat ini dapat dipasang pada sepeda motor dan berfungsi sebagai sistem keamanan ganda. Dalam melakukan proses penelitian, dilakukan beberapa tahapan, diantaranya adalah tahap pengamatan (observasi) di laboratorium terhadap pengujian modul rangkaian. Selanjutnya dilakukan tahap perancangan perangkat keras dan perangkat lunak yang dimulai dari bulan juni sampai dengan desember 2019. Selanjutnya dilakukan tahapan pengujian untuk pengambilan data percobaan dari setiap modul rangkaian yang ada. Setelah dilakukannya pengujian baik komponen hardware maupun software, maka kemudian dapat disimpulkan bahwa perancangan dari pada sistem keamanan pada sepeda motor tersebut dapat diimplementasikan.

\section{HASIL DAN PEMBAHASAN}

\section{Pengujian Sistem Rangkaian}

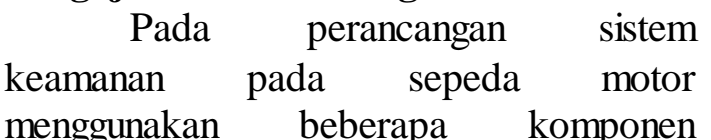
elektronika diantaranya mikrokontroler arduino uno sebagai media pengontrolan utama yang mana pada mikrokontroler arduino uno di program untuk mendeteksi RFID card. RFID reader \& card sebagai media pengganti kunci untuk menyalakan mesin pada sepeda motor. Modul relay sebagai sakelar otomatis yang ketika RFID card ditempelkan pada RFID reader maka model relay akan aktif sehingga arus listrik dari baterai mengalir ke dinamo starter sehingga mesin pada sepeda motor menyala. Baterai yang merupakan sumber tengan utama untuk mensuplai energi listrik ke mikrokontroler arduino uno dan komponen pendukung lainnya. Sistem keaman menggunakan RFID ini menggantikan peran kunci kontak yang biasa pada sepeda motor. Sehingga RFID dapat memberikan tingkat keamanan yang lebih dari sebelumnya. Untuk memastikan sistem ini berjalan lancar dan sesuai harapannya, maka dilakukan beberapa pengujian \& percobaan pada setiap rangkaian.

\section{Pengujian Baterai}

Dalam perancangan sistem kendaraan bermotor ini digunakan sebuah baterai dengan jenis AKI. Baterai AKI yang merupakan sumber tegangan searah (DC) ini memiliki tegangan 12VDC. Baterai AKI merupakan sumber energi yang berperan sebagai pengganti dari pada Catu Daya (Power Supply). Baterai AKI juga termasuk kedalam sumber tegangan portable yang bisa dibawa kemana saja. Dalam prose pengujian baterai, dibutuhkan sebuah alat pengukur daya yaitu Multimeter.

Adapun langkah pengujian baterai sebagai berikut:
1. Sediakan
Multimeter
(dalam pengujian ini menggunkan Multimeter Digital)

2. Kalibrasi Multimeter pada skala 20 VDC

3. Hubungkan jack merah multimeter pada kutub positif baterai \& jack hitam pada kutub negatif baterai

4. Pada LCD Multimeter akan tampil besar tegangan dari baterai.

Dari pengukuran yg dilakukan, besar tegangan baterai adalah 12,68 VDC. Hal ini menunjukkan bahwa baterai/Aki masih dalam kondisi baik/normal. Berikut merupakan gambar pengujian baterai. 
DOI: https://doi.org/10.33330/jurteksi.v7i2.1060

Available online at http://jurnal.stmikroyal.ac.id/index.php/jurteksi

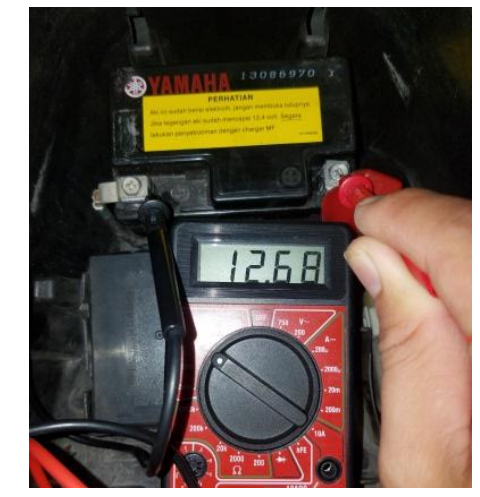

Gambar 1 Pegujian Baterai

\section{Pengujian Arduino Uno}

Arduino Uno merupakan sebuah media atau modul pengontrolan tunggal dengan menggunakan sebuah chip mikrokontroler Atmega 328p. Dalam proses pengujiannya, dilakukan dengan cara memberikan tengan dari adaptor sebesar 12 volt serta ditanamkan sederet program dasar untuk menyalakan sebuah media indikator berupa led. Modul Arduino Uno dikatakan dalam kondisi baik, maka akan ditunjukan dengan menyalanya lampu indikator pada modul Arduino Uno. Berikut ini merupakan gambar dari pengujian modul mikrokontroler Arduino Uno.

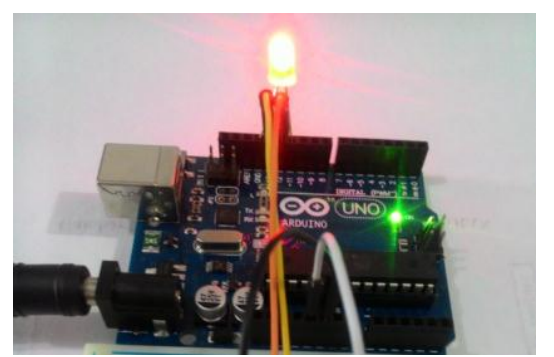

Gambar 2 Pegujian Arduino Uno

Adapun listing program yang digunakan dalam melakukan pengujian pada modul Arduino Uno sebagai berikut.

int led $=11$;

void setup ()

\{ pinMode (led, OUTPUT); \}

void loop ()

\{ digitalWrite (led, HIGH); \}

\section{Pengujian Modul Relay}

Modul relay merupakan sebuah komponen sakelar otomatis yang sering digunakan dalam pembuatan alat kerja berupa pengontrolan melalui mikrokontroler maupun PLC. Dalam proses pengujiannya rangkaian relay diberi daya sebesar 5VDC. Tegangan tersebut diambil dari port VCC Modul Arduino Uno dan pin input modul relay dihubungkan langsung dengan pin output modul arduino uno. Dimana modul arduino uno tersebut sudah di tanamkan sederet program untuk menyalakan dan mematikan modul relay. Sehingga ketika program yang diproses oleh Arduino berlogika 1 (satu), maka relay akan menyala (aktif), sebaliknya ketika program yang di proses Arduino berlogika 0 (nol), maka relay akan padam (tidak aktif). Adapun gambar proses pengujian modul relay yang dihubungkan dengan modul Arduino Uno pada gambar 3 .

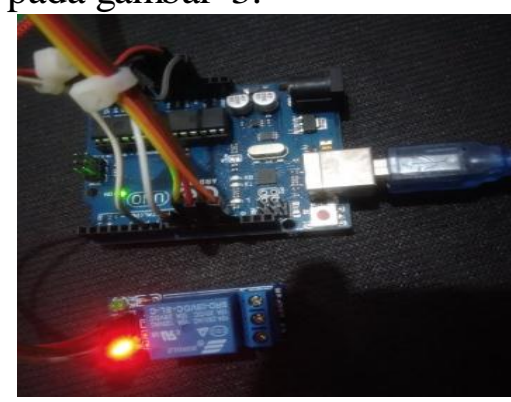

Gambar 3 Pegujian Relay

Adapun listing program yang ditanamkan pada modul Arduino Uno untuk pengujian terhadap modul relay sebagai berikut.

int relayPin $=7$;

void setup()

\{ pinMode(relayPin, OUTPUT); \}

void $\operatorname{loop}()$

\{ digitalWrite(relayPin, LOW);

delay(5000);

digitalWrite(relayPin, HIGH);

delay(5000); \} 
DOI: https://doi.org/10.33330/jurteksi.v7i2.1060

Available online at http:/jurnal.stmikroyal.ac.id/index.php/jurteksi

\section{Pengujian Rangkaian Keseluruhan}

Pengujian rangkaian keseluruhan dapat dilakukan setelah pengujian rangkaian satu persatu. Setelah itu rangkaian tersebut saling dihubungkan, yakni rangkaian catu daya, Mikrokontroler Arduino Uno, rangkaian RFID dan rangkaian Relay. Dalam pengujian keseluhuran rangkaian Mikrokontroler Arduino Uno terlebih dahulu di program sesuai dengan kebutuhan kita. Di mana tujuan alat ini di rancang untuk menyalakan sepeda motor. Dalam hal ini fungsi rangkaian Relay sebagai sakelar otomatis menyalakan starter sepeda motor.

Sistem kerja alat yang dibangun adalah e-KTP yang dalam hal ini sebagai kunci ganda dalam menyalakan sepeda motor. Chip yang terdapat pada e-KTP sebelumnya di registrasikan terlebih dahulu pada RFID Tag. Sebelumnya program yang di upload pada arduino memberikan layanan registrasi chip ektp. Setelah e-KTP tersebut sudah ter rigistrasi, maka e-KTP tersebut sudah dapat digunakan sesuai dengan kebutuhan peneliti, yaitu sebagai kunci ganda untuk menyalakan sepeda motor. Adapun gambar dari rangkaian keseluruhan dapat dilihat pada gambar berikut ini.

$$
\text { Pada pengujian pertama, }
$$

dilakukan dengan menggunakan RFID Tag yang belum terdaftar atau chip yang ada pada RFID Tag belum di registrasi pada RFID Reader. Sehingga ketika RFID Tag di tempelkan pada RFID Reader, maka Led indikator berwarna putih menyala namun pada rangkaian relay tidak aktif hal ini ditandai dengan tidak menyalanya led hijau pada rangkaian relay.

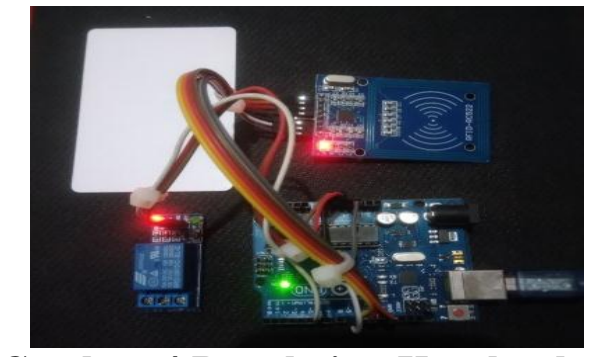

Gambar 4 Rangkaian Keseluruhan

Adapun gambar dari proses pengujian pertama dengan RFID yang belum di register sebagai berikut ini.

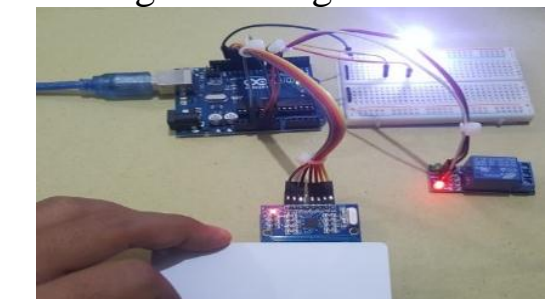

\section{Gambar 5 Pengujian Rangkaian} Keseluruhan Pertama

Pada pengujian selanjutnya yang dilakukan adalah dengan cara menempelkan RFID Tag yang sudah di registrasi. Di mana chip yang ada pada RFID Tag di daftarkan terlebih dahulu pada RFID Reader. Sehingga data pada chip RFID Tag tersimpan pada chip Arduino. Pada proses pengujian kedua ini ketika RFID Tag yang sudah terregistrasi tadi di tempelkan pada RFID Reader, maka led indikator putih sebagai tanda adanya RFID Tag menyala dan disertai aktifnya rangkaian relay. Aktifnya rangkaian Relay ditandai dengan menyalanya led indikator berwarna hijau. Adapun pengujian kedua pada gambar 6 .

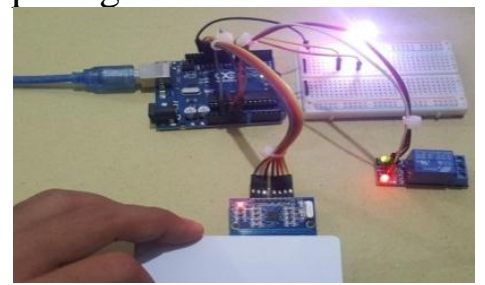

Gambar 6. Pengujian Rangkaian Keseluruhan kedua 
DOI: https://doi.org/10.33330/jurteksi.v7i2.1060

Available online at http:/jurnal.stmikroyal.ac.id/index.php/jurteksi

\section{SIMPULAN}

Sistem keamanan dengan menggunakan RFID berbasis mikrokontroler ini sangat membantu pengguna dalam mengamankan sepeda motornya. Di mana untuk menyalakan sepeda motor, RFID tag/card harus di tempelkan ke RFID reader terlebih dahulu. Secara teknis relay yang akan mengubungkan dan memutus aliran listrik pada mesin \& dinamo starter. Dari pengujian yang sudah dilakukan diatas, semua tampak layak dan memberikan hasil yang maksimal. Sistem keamanan ini juga dapat diterapkan pada kendara roda dua \& roda empat maupun lebih.

\section{DAFTAR PUSTAKA}

[1] D. Saputra, D. Cahyadi, and A. Harsa Kridalaksana, "Sistem Otomasi Perpustakaan Dengan Menggunakan Radio Frequency Identification (RFID)," J. Inform. Mulawarman, vol. 5, no. 3, pp. 111, 2010.

[2] "Badan Pusat Statistik, jumlah kendaraan bermotor (unit) 2018," Wikipedia. 2018, [Online]. Available:

https://www.bps.go.id/link/Table Dinamis?view/id/1133.

[3] M. I. B. Zainal Muttaqin, Desi Kisbianty, 'Perancangan Sistem Keamanan Sepeda Motor Menggunakan," J. Ilm. Media Process., vol. 10, no. 2, pp. 1-11, 2015.

[4] M. H. Kurniawan, S. Siswanto, and S. Sutarti, "Rancang Bangun Sistem Keamanan Sepeda Motor Dengan Sidik Jari Dan Notifikasi Panggilan Telepon Berbasis Atmega 328," PROSISKO J.
Pengemb. Ris. dan Obs. Sist. Komput., vol. 6, no. 2, pp. 152165, 2019.

[5] D. Andesta and R. Ferdian, "Sistem Keamanan Sepeda Motor Berbasis Mikrokontroler dan Modul GSM," J. Inf. Technol. Comput. Eng., vol. 2, no. 02, pp. 51-63, 2018

[6] F. A. IMBIRI, N. TARYANA, and D. NATALIANA, "Implementasi Sistem Perparkiran Otomatis dengan Menentukan Posisi Parkir Berbasis RFId," ELKOMIKA J. Tek. Energi Elektr. Tek. Telekomun. Tek. Elektron., vol. 4, no. 1, p. 31, 2018

[7] R. Hamdani, I. H. Puspita, and B. D. R. W. Wildan, "Pembuatan Sistem Pengamanan Kendaraan Bermotor Berbasis Radio Frequency Identification ( Rfid )," Indept, vol. 8, no. 2, pp. 56-63, 2019, [Online]. Available: http:/jurnal.unnur.ac.id/index.php /indept/article/download/290/278.

[8] A. Z. Hasibuan, H. Harahap, and Z. Sarumaha, "Penerapan Teknologi RFID Untuk Pengendalian Ruang Kelas Berbasis Mikrokontroler," $J$. Teknol. dan Ilmu Komput. Prima, vol. 1, no. 1, pp. 71-77, 2018

[9] S. T. M. T. Fernando Napitupulu Ekki Kurniawan, S.T., M.S.c. Cahyantari Ekaputri, "1 123 1," vol. 4, no. 2, pp. 1449-1456, 2017.

[10] B. O. Arfian, "Pembuatan Sistem Keamanan Kendaraan Bermotor Roda Dua Menggunakan Rfid," $J$. Mhs. Tek. Inform., vol. 3, no. 1, pp. 72-78, 2019, [Online]. Available: https://ejournal.itn.ac.id/index.php /jati/article/view/2515. 